\title{
NIGERIANS UTILISATION OF CODE-MIXING AS COMMUNICATIVE DEVICES
}

\author{
Iyabode Omolara Akewo Daniel \\ National Open University of Nigeria, Abuja \\ Email: akewoauthe@gmail.com \& idaniel@noun.edu.ng
}

APA Citation: Daniel, I. O. A. (2016). Nigerians utilisation of code-mixing as communicative devices. English Review: Journal of English Education, 5(1), 101-114

Published: 01-12-2016

\begin{abstract}
The importance of communication as a central idea in language usage cannot be over-emphasised. This seems to inform how many Nigerian speakers make extensive use of the mixture of indigenous languages and the English language in one and the same breath. It seems to reveal a kind of perception of reality in two ways at the same time. They seem to go through the process of thinking in diverse ways at the same time. This study thus seeks to find out the extent to which the average Nigerian user of the English language makes intelligible contribution to discourses. How much sense is made to and by interlocutors in the course of their discussions? To what extent is reality to them influenced by their knowledge of the English language? The extent of the indigenisation process is also of interest to the study. The expectation is that such contact should be to the advantage of one or the other of the languages in contact. Real time linguistic data were collected and analysed, using linguistic levels as base to access the extent to which Nigerian indigenous languages have been able to influence the English language. The finding shows that codemixing is an important part of the Nigerian communication process and has enabled the vernacularisation of the English language to a very large extent. This has produced a new spatial identity that reveals the Nigerian's domination of the colonial English language.

Keywords: Code-mixing, Communication, Language usage, English vernacularisation, Nigerian indigenous languages, Spatial identity
\end{abstract}

\section{INTRODUCTION}

The English language came in contact with the Nigerian people about five centuries ago when the Britons first landed on the Nigerian shores for commercial purposes (Oyeleye, 1990; Osakwe, 2005). The missionary activities that followed further strengthened the inroad by the English language into the Nigerian society while the annexation of Lagos in the $19^{\text {th }}$ Century and the subsequent colonisation of Nigeria in the $20^{\text {th }}$ Century solidified the hold of the English language on Nigeria (Oyeleye, 1990; Spencer, 1971).

With English now being used for administrative purposes, it was only a matter of time before it permeated the entire national life of Nigeria. Moreover, because the colonial administration had need of such manpower like clerks, typists, etc., it decided to train some 'natives' for this purpose. This turned English into a language with some potential economic advantage. Subsequently, many people struggled to learn this language. It also became a 'language of high culture' to many as it remained the essential language of the white man's religion (Spencer, 1971). All these factors facilitated the implantation and expansion of English in Nigeria.

However, the Nigerian society has the indigenous languages. These 
languages, which were already advanced themselves, easily accommodated the new phenomenon that came to their shores. Such new lexical terms like 'buredi' from bread, 'șia' from chair (examples are from the Yoruba language of the South West Nigeria) etc. were created (cf. Bamgbose, 1995; Daniel, 2011).

Another resultant effect of this contact was the pidginisation of English. 'Pidgin English', which Odumuh (1993) refers to as 'the lingua franca defacto' ( $\mathrm{p}$. 1 ), serves as the language of widest communication among educated and non-educated Nigerians alike. It was developed among the Niger Delta people, with whom there was the earliest contact. It flourishes widest among them till date. It has even moved to the point of attaining Creole status among some of the people of the area (Osakwe, 2005). The very multi-ethnic and consequently multi-lingual nature of the Nigerian society probably makes this simplified form of English the most extensively used.

Ubahakwe (1979) puts the literacy rate in Nigeria at probably less than $20 \%$ and those employed by the government as being less than $25 \%$ of the 80 million Nigerians (p. ix) at that time. The 1991 population suggests the literacy rate to be an average of $50 \%$. The 2006 census, which is the current population census on which the Nigerian population is based, appears to have doubled the population figure. However, the same cannot be said of the literacy rate as adult literacy rate averages $64.8 \%$ in the 2010 survey by the National Bureau of Statistics (2010) while the literacy of the youth indicates a much higher and hopeful figure of $81 \%$.

Nonetheless, it will be interesting to know what happens to the remaining number of Nigerians that have not had any contact with the formal education system within which the English language is learnt. This is in the light of the disparity in the literacy levels of the states. On the heels of this is the Boko Haram real time threat to education with its evil attacks on schools and worse still, the recent abduction of young school girls in the purported educationally disadvantaged North.

In addition, it was noted in the survey referred to above that the tendency is that the literacy level in English is usually lower than in all the other languages in the country. Therefore, Odumuh (1993), quoting Omolewa (1979), suggests that this remnant of the population that have to live with English as their second language might have developed a variant that mixes the indigenous language and the few words of English they know together for communication purposes. This variety, which is tagged non-standard, may be a way of not allowing themselves to be silenced (Osundare, 1982) by the elites.

This, once again, appears to show the resilience of the average Nigerian in adapting to situations that one would consider intolerable. The very fear expressed by Osundare (1982) may not be unfounded, but he forgets that the English language itself has been 'colonised' (Odumuh, 1993) by the Nigerian. This is not to say that an alternative indigenous language will not be better, but the reality of the uproar that may result is the fear that had been proven times over by the suspicion with which people view any language policy that does not favour them. This may account for the very way the Nigerian had instead made the language that is considered 'neutral' subject to their very needs and environment (Daniel, 2012).

Bilingualism seems to be prevalent in the Nigerian society, but what was 
actually discovered is that: while some may truly be bilingual in terms of functional bilingualism, that is have passable knowledge of a Nigerian language and English (not necessarily coordinate knowledge), the majority of Nigerians are actually able to use up to three to four codes, depending on where $\mathrm{s} /$ he comes from and the context (cf. Essien, 1995). This fact is demonstrated in the data collected for this study. From the educated to the not-so-well educated, the rate at which they switch from one code to the other without losing intelligibility is amazing. It is therefore sensible that the code-mixing usage of Nigerians be investigated to ascertain the communicative effectiveness of such usages in interactions among interlocutors of different levels.

Code-mixing has been defined as the mixing together of two codes in a communication event. Essien (1995) asserts that code-mixing arises due to language contact as well as communication convenience. He argues that code-mixing is usually done in informal contexts. To him, a person that code mixes may not necessarily do same in a formal situation. However, he observes that most interlocutors use code-mixing to arrive at solidarity status in a manner which usually makes it impossible sometimes to determine the educational status of those involved. He nonetheless notes that a dangerous trend that the practice portends is that of being viewed as a threat to the Nigerian indigenous languages. Even then, he agrees with Lamidi (2003) that the syntactic structure of code-mixing actually has a structural pattern.

Nevertheless, the concern in this paper is the communicative usefulness of code-mixing. The fact is that the effectiveness of communication is what language usage is all about. It needs be mentioned here that, contrary to Essien (1995) assertion, Wardhaugh (2006) sees code-mixing and code-switching as one and the same. All the same, Wardhaugh agrees with this researcher's position that, essentially, code-mixing is done principally to communicate.

Communication, to all intent and purposes, is usually described as a transfer of information from sender to the receiver of the message. Wikibook.org (2013, p. 3) defines it as “...how humans share, encode, and decode what they know, what they need, and what they expect from each other." Weilenmann (1962) sees communication in terms of transfer of messages containing quantities of information. To him, information controls the human behaviour. This means that the source (sender) of the information tends to control the behaviours of others through carefully determining what sort of information is passed. However, one could find fault with this kind of definition in that, clearly, the receiver of information is not usually dormant in processing the information received. Nonetheless, it cannot be disputed that the kind of information one is fed with tends to affect the way one responds to situations at times (cf. van Dijk, 1995). In this way, his observation that the kind of information the decision maker in an organisation passes across could determine the behaviour members of that organisation (or society, for that matter) exhibits.

An interesting part of the definition of communication is that it is seen as assigning meaning content or interpretation to a discourse (Daniel, 2013). Semantic functioning of language being related to its meaning content is an important view of communication processing. Folarin (1998) asserts that communication is basically the ability of 
the speaker to get across the meaning they intend communicating to their interlocutor(s). This paper therefore seeks to find out how meaning exchanges and semantic processing are contributory to the communication effectiveness in linguistic exchanges among Nigerians, even within the seeming limitation of a 'foreign' language and, sometimes, diverse linguistic backgrounds of the interlocutors.

If language is essentially meant for communication (cf. Daniel, 2012; Essien, 1995), beyond mere artistic gymnastics,

i. How much has English as an inherited second language been effective in its usage for communication among Nigerians?

ii. How well have the indigenous communities been able to naturalise the English language to their particular purposes, considering the reality of English as an unavoidable 'legacy' of colonialism in today Nigeria?

These are the concerns of this paper.

\section{METHOD}

Participant/observant method was employed in gathering the data. Many speech events in which the author was either a participant and/or an observer were variously recorded. However, these two were finally purposively selected. Of the two events used for this investigation, the first group (GP I) has a multi-ethnic mixed population of educated and non-educated Nigerians as interlocutors while the second group (GP II) has two Yoruba bilingual speakers engaging in the interlocution. The second group has university education, which is of interest to the investigation in order to compare the employment of code mixing by the diverse interlocutors in the two speech events. In the first speech event, the writer visited a pools agency where some men, numbering eight, were playing cards and draft. She sat among them and participated in their discussions.

The second speech event was done along the Agbowo Road, opposite the University of Ibadan main gate. The participants in this second speech event are two young people: a young lady and a young man; the author was a mere observer of this second event. These were students of the University of Ibadan. This second event was meant to serve as a kind of control variable in order to allow for a comparative datum with that collected from the first group, which seems to be a sort of a mix-bag educationally, socially, economically and ethnically. The data collected from these groups were orthographically transcribed. These served as appendices 1 and 2, presented at the end of this paper.

The data analysis was done using the application of the occurrence of codemixing features as seen at different linguistic levels of their manifestation. These were indicated and discussed as identified in the data. Their communicative usefulness or effectiveness is the focus of identification or discussion in the next section.

\section{RESULTS AND DISCUSSION Code-mixing}

The commonest feature found to be a major trend in the linguistic employments of the subjects in the two groups is code-mixing. The groups examined are investigated from the angle of the rate at which they code-mix Yoruba, which is the prevalent regional language in the geographical area covered in the investigation, is constantly being used together with the English language. It seems to pose no 
difficulty to the interlocutors in expressing themselves in each case as well as in understanding the meaning intended by the speaker.

For example:

\section{GP I}

D: Shokoloko bangbose, spell e. [nonsensical words]

E: O easy baje. Sho...ko...lo...ko... [It is so easy. (Attempting to spell the nonsense words)]

A: Eyin e spell e n'gba t'eyin mo (to D) [You should spell it as you know it]

B: So gbo ni sin in. Won ni k'e spell e $\mathrm{n}$ gba t'e mo. [Can you hear that. You are told to spell it as you know it.]

A: Teacher o ki i teach ba yen. Eyin e spell e. [A teacher doesn't teach in this manner. You spell it. (insisting to D)]

$\mathrm{C}$ : Bi won se $\mathrm{n}$ teach ni sin ni yen. [That is the manner being engaged in teaching these days.]

\section{GP II}

Y: So, ko try lati intensify efforts e. [So, you should try to intensify your efforts.]

Z: Ma wa wa. Church kan na l'emi ati woman yen jo nlo. [I will come to look for her. That woman and I attend the same church.]

The rate at which the interlocutors shift from one code to another is surprising. Odumuh (1993, pp. 23-24) contends that the Nigerian does not lose a particular lect of English once acquired as implied by Bickerton's theory of scalogram lect. Instead, he opines, the Nigerian learning all the available varieties like pidgin, broken (patois), non-standard and educated varieties (if $\mathrm{s} /$ he is educated) may have them all present in their repertoire. S/he therefore switches to any of these codes as occasion demands. However, Essien (1995) opines that context has a lot to do with the possible occurrence of codemixing for the Nigerian speaker as demonstrated in the case of Ibibio/English bilinguals. Further examples could be seen in the data below:

\section{GPI}

F: Who knows the new minister for education? [some muffled comments]

F: Na Jamaican English we want to dey use now. [We want to start making use of Jamaican English now.]

A: Where una for dey learn that one? [(curiously) Where did you learn that one from?]

... Ah! ah! (general laughter)

A: I'm interested o. [I'm really interested.]

F: What is the need now? [What is the need?]

A: I'm a student of English, I want to know. Where did you learn Jamaican English?

$\mathrm{B}$ : Ah, o n sere. [He is joking.]

G: Riddles and jokes ni. [It is riddles and jokes.]

A: Oh, oh. But se eyin mo ipe there is Jamaican English? [Oh, oh. But do you know that there is Jamaican English?]

F: Well...

G: This man is from Jamaica. 
The way the interlocutors easily moved from the Standard English structures to Yoruba, to pidgin English and to the non-standard English is surprising to say the least as noted above. It, however, goes to prove Odumuh's (1993) claim as stated above. Moreover, it reveals that the interlocutors have a smattering command of all the languages involved, which makes communication to flow. This also agrees with Wardhaugh's (2006) assertion that many language users are actually multilingual and they operate in all the languages as the need arises. Even though in the course of the exchanges in the data it was discovered that the participants are from different ethno-linguistic groups in Nigeria, the languages being employed appear to have been adapted to suit their needs for communication without leading to a semantic breakdown or misunderstanding. This goes to show that linguistic integration is possible in Nigeria if policy makers will think seriously about finding a language of communication beyond mere artistic embellishment.

This phenomenon is virtually nonexistent in the second group, probably due to the fact that they are more strictly bilingual Yoruba/English speakers. It appears to also reveal a fact that pidgin may be flowing more among the heterogeneous group than among the ethnically homogenous group. In Edo and Delta States, which had been called a mini-Nigeria (when it was the defunct Bendel State), due to the multilingual nature of the area, pidgin is virtually the language of official communication after English, as found by this writer as a teacher of the English Language in a secondary school in Edo State between 1993 and 1996 (cf. Osakwe, 2005). This problem is apparently absent amongst the homogenous groups such as the Yoruba that seem to have only their mother tongue (Yoruba) to contend with as demonstrated by GPII.

\section{Phonological Level}

Code transfer is another important area that is observed in the participants' linguistic employments. Interlocutor $\mathrm{F}$ pronounces /trezə:/ as [tre $\left.\int\right]$, which may be accounted for as due to a lack of the sound /3/ in any Nigerian language. Moreover, the English language as a whole seems to be pronounced in such a manner that you will almost imagine another Nigerian indigenous language is being spoken rather than English when it is spoken as a stretch of sentence.

For example:

A: I am interested o.

The addition of 'o' thus nullifies the sentence as strictly English in terms of pronunciation. It appears like any Nigerian language being spoken. It should be stated that this element is actually an emphatic one. It, however, proves Lamidi (2003) point that Yoruba head parameter is actually a major determinant of the structural form of the structures produced by the Yoruba/English bilinguals (see Bamgbose, 1995) for the same position on the English code-mixed structures). For Akinjobi (2004), this is a major feature exhibited by her subjects in her inquiry into some pronunciation tests undertaken by some Educated Yoruba English speakers. Code transfer is thus a feature common in the use of language by these speakers. And it is obvious that it did not detract from the communication process as the communication process never experienced a hitch in the course of that section of the exchanges. Obviously, then, the domestication of the English 
ENGLISH REVIEW: Journal of English Education Vol. 5, Issue 1, December 2016
ISSN 2301-7554

https://journal.uniku.ac.id/index.php/ERJEE language is an effective one as it enabled communicative functionality.

\section{Syntactic Level}

Structures are given that would almost sound unintelligible to an outsider (i.e. a non-Nigerian) that does not have an idea of the language of the discussants. Such element as exemplified below could be seen in the data.

A: Why now? You are a citizen now? F: There is election for sale.

The unnecessary addition of 'now' to A's question instead of just a bare 'Why? But you are a citizen?' (said in a questioning manner) and F's use of 'election' instead of 'votes' demonstrate localised usages. This is again seen in $\mathrm{F}^{\prime} \mathrm{s}$ 'You know Bob Marley' when he actually means to ask if his addressee has heard of Bob Marley.

All these syntactic and lexical differentiations reflect, not so much a bastardisation of the English language, but the people's world view. It seems a reality of what the language had been adapted to become in the nation. It appears to be a validation of Whorf's (1956) view of language as a result of the thinking system of its users and for their own purposes and ends. Apparently then, Daniel (2012) argues that transliteration is a communication weapon in the Nigerian milieu could be justified by this data. It thus appears that the argument for the Pidgin English as an important part of the Nigerian national life in terms of its functionality could also be advanced here for this case. It would seem then that rather than see these syntactic 'malapropisms' as such, their communicative effectiveness should determine their linguistic value. As the reality that stares all scholars of the English language in the face every day is that it can no longer be denied that the English language actually has become domesticated in many locations where it once dominated (cf. Bamgbose, 1995). There exists Indian English, Nigerian English, Australian English, Kenyan English, Ghanaian English, etc. as examples of the nativised options. Even within Nigeria, there are variants such as Yoruba English, Hausa English, Igbo English, etc. You do not just not speak in the indigenous languages now but you speak the English that your kith and kin can understand; otherwise 'you are on your own' (to use a local parlance). What does this mean? Communication breakdown.

This paper examined the origin of the English language in Nigeria and how it came to be planted. It also looked at the relationship between the Nigerian and this 'Caliban's curse' (Osundare, 1982). The study analysed two complementary speech events to determine if there is any effect of educational attainment on the English language and its domestication. It also tried to find out if, despite being a colonial heritage, the Nigerian has turned round to 'colonise' the English language.

As much as the paper realises that the language has not been without its effects on the local languages, it contends that the local environment had not been without effect on English as well (see Daniel, 2012). It also found that given the present reality of the Nigerian linguistic situation, the domestication of the English language can give the Nigerian speech community what Odumuh (1993) calls 'linguistic independence' without being the worse for it. If the language seems to tend towards communication for economic growth facilitation, the very fact that the heterogeneous GPI can communicate so effectively with all the available repertoire at their disposal 
seems to suggest that, as Banjo (1995) puts it, "bilingual education is ideal for all the nation's citizens" (p. 184). Where even feasible tri- to quadri-ligual education should be made available to the Nigerian citizen that is interested, otherwise, the 'lingua franca' pidgin can serve unofficially and informally as the language of communication.

However, the best option seems to be to teach Standard English, with Nigerian colour just because of its exoglossic status while trying to maintain it as a level of symbiotic relationship with the Nigerian indigenous languages as was found in the pool house discourse. Bamgbose (1995) perceptibly notes that in any situation of language contact, "the resulting linguistic influence is mutual." This writer agrees with him as revealed in the analysis of the data above. So, the issue of domination of English does not even arise as its vernacularisation is actually a testimony of its succumbing to the Nigerian environmental influences.

\section{CONCLUSION}

From the analysis and discussion above, it appears that what the Nigerian speech community needs is a means of communication. If despite the heterogeneous nature of the first group of interlocutors it kept its communication flowing, the contention here then is that the Nigerian nation should consider the emergent Nigerian English as a good thing because English as an exoglossic language may still smart of the colonial heritage. But such language policy should also make sure that a symbiotic relationship is built between the Nigerian languages and the English language. Such can be achieved through the encouragement of respect for the indigenous languages and their being taught in the curriculum. This will foster the kind of linguistic plurality which is positive as observed in GPI. It should go beyond paper work; attempt at implementation should be seriously made.

Moreover, pidgin/non-standard English, which seems to help towards wider communication can help in the economic growth as those that are really the workers use it, as well as many educated Nigerians. Therefore, it should not be downgraded; instead, efforts at not substituting it for the real thing (Standard Nigerian English) should be made in the course of teaching.

In addition, it is necessary that the English scholars in Nigeria should make serious attempts at codifying the Nigerian English. As stressed by Bamgbose (1995) and Daniel (2012), the Nigerian English is a reality and can no longer be denied as exemplified in the works of these scholars as well as in the data in this paper; codifying and standardising it appears to be a sensible course of action. It is thus heartening that the Nigeria English Studies Association conference of 2010 was basically focused on doing something about this. A step further is taking concrete action to actualise this in order to save the Nigerian nation from the present confusion over the matter. The mix bag of British and American English is the present albatross that the Nigerian speakers of English argue over as observed by this researcher (cf. Bamgbose, 1995). One will also wish to suggest the need for a clear language policy by the Nigerian government. The present idea of subsuming it in the National Policy on Education (Federal Republic of Nigeria, 2004) does not appear to be forward looking. This is why most people are confused as to if Nigeria actually has a language policy. 


\section{ACKNOWLEDGEMENTS}

I wish to acknowledge the cooperation of the shop owners where I did the recording of the many speech events from among which only these two were used for this study. I also wish to acknowledge the participants that gave the data used for this research. In the same vein, I wish to acknowledge Mr. Bolounduro Oke-Job who gave me the tape recorder that was used for the recording of the speech events.

\section{REFERENCES}

Akinjobi, A. (2004). The duration and quantity factors in educated Yoruba spoken English: The realization of syllables with syllabic consonants as peaks. Ibadan: Journal of English studies. 1, pp. 88-99.

Bamgbose, A. (1995). English in the Nigerian environment. In A. Bamgbose, A. Banjo, A. Thomas (Eds.) New Englishes: A new West African perspective, (pp. 926). Ibadan: Mosuro.

Banjo, A. (1995). On codifying Nigerian English: Research so far. In A. Bamgbose, A. Banjo, A. Thomas (Eds.). New Englishes: A new West African perspective, (pp. 203-232). Ibadan: Mosuro.

Daniel, I. O. (2011). Introductory phonetics and phonology of English. Newcastle upon Tyne: Cambridge Scholars Publishing.

Daniel, I. O. (2012). Transliteration as communication weapon in Nigerian English. Journal of Nigerian English studies association. 15(2), pp. 98-117.

Daniel, I. O. A. (2013). Communication as socio-cultural meaning exchange: The example of Richard Wright's Black Boy. International journal of applied linguistics and English literature, 2(5), pp. 173-177.

Essien, O. (1995). The English language and code-mixing: A case study of the phenomenon in Ibibio. In A. Bamgbose, A. Banjo, A. Thomas (Eds.) New Englishes: A new West African perspective, (pp. 269-283). Ibadan:

Mosuro.

Federal Republic of Nigeria. (2004). National policy on education ( $4^{\text {th }}$ edition). Lagos: NERDC Press.

Folarin, B. (1998). Theories of mass communication: An introductory text. Ibadan: Stirling-Horden Publishers (Nig.) Ltd.

Hanafi, A. (2009). Indigenous languages as 'developmentals'. POLIS journal, 1. Accessed 11 May, 2014 at www.polis.leeds.ac.uk/assets/files /students/.../adham-hanafi-summer09.pdf.

Lamidi, M. T. (2003). The head parameter and grammaticality in Yoruba/English code-switching among undergraduates in selected Nigerian universities. PhD Thesis. University of Ibadan.

National Bureau of Statistics. (2010). National literacy survey. Abuja: Federal Republic of Nigeria.

Odumuh, A. E. (1993). Sociolinguistics and Nigerian English. Ibadan: Sam Bookman.

Osakwe, M. (2005). Welcome English...and how long English in Nigeria

West Delta multilingual communities? Journal of the Nigeria English studies association. 11(1), pp. 11-23.

Osundare, N. (1982). Caliban's curse: The English language and Nigeria's underdevelopment. Ufahamu: A journal of African studies. 11(2), pp. 96-107.

Retrieved

from http://escholarship.org/uc/item $\angle 8972$ w2s0 on 14 May, 2014.

Oyeleye, A. L. (1990). Nigeria English: A reexamination of some historical and sociolinguistic factors. Journal of the Nigeria English studies association.

Spencer, J. (Eds.). (1971). The English language in West Africa. London: Longman.

Ubahakwe, E. (1979). Introduction. In E. Ubahakwe (Eds.) The teaching of English studies: Readings for colleges and universities, (pp. ix-xiv). Ibadan: Ibadan University Press. 
Van Dijk, T. A. (1995). The mass media: Discourses of domination or diversity. Discourse in society. http://www.discourse.org/Ol dArticles/Themediatoday.pdf. Accessed February 18, 2008.

Wardhaugh, R. (2006). An introduction to sociolinguistics (5th edition). Oxford: Blackwell.

Weilenmann, A. (1962). Communication theory in international relations. The western political quarterly. 15(3), pp. 47-48. Accessed 10 April, 2015 from http://www.jstor.org/stable/445614.

Whorf, B. L. (1956). Language, mind and reality. In J. B. Carroll (Eds.) Languages, thought and reality: Selected writings of Benjamin Lee Whorf, (pp. 246-270). Massachusetts: MIT.

Wikibook.org. (2013). Communication theory. Retrieved 2 May, 2015 from https://upload.wikimedia.org/ wikipedia/commons/5/51/Communi cation_Theory.pdf 


\section{Appendix I}

Context: playing of draft and cards by the participants

Participants: Seven men and a woman

Location: Pools Agency Store

Appellation: Alphabetic Labels of Participants Interlocutor

A: Se ma f'owo si ni sin ni? ...... Okay, twenty-five ti won se yen je ona mewa

G: Jamaican ni Bobo yen ke

C: Jamaican ko, Canadian ni

D: Shokoloko ba ngbose, spell e. O easy baje

E: Shokoloko...

A: Eyin e speli ngba t'eyin mo

B: Sho gbo ni sin in. Won ni ke spell e ngba t'e mo.

A: Teacher o $\mathrm{k}$ ii teach bayen. E yin e spell e.

$\mathrm{C}$ : Bi won se $\mathrm{n}$ teach ni sin ni yen.

F: 1940 something.

F: Who knows the new minister for education?

F: Na Jamiacan English we want to dey use now

A: Ah, ah, where una for learn that one?

(general laughter)

A: No, I'm interested o.

F: What is the need now?

A: I'm a student of English; I want to know. Where did you learn Jamaican English?

B: O ns'ere ni.

G: Riddles and joke ni.

A: Oh, oh. But se eyin mo i pe there is Jamaican English?

F: Well...

G: This man is from Jamaica.

A: Eeh, eh. Is that so? Pleased, to meet you. What is the name?

F: Korika.

A: Ah!

F: Korika.

A: O pari! (laughter). Una go dey sey fifty naira for ...

B: Ta lo wo Bombay to Goar?

(echoes of Bombay to Goar)

B: Ikan mu ika lati Bombay de Goar.

A: Se awon footballers?

$\mathrm{F}$ : Me, I no go cast my own vote again.

A: For the one wey den dey do now?

F: Eh en.

A: Why now? You are a citizen now.

F: There is election for sale. 
A: Election for sale? You are a citizen now?

F: Ci...

A: Citizen.

F: For Algeria or for Jamaica? Ki lo n j'ebe?

A: E gbo Yoruba tele? I be think you be Igbo o.

F: Ibo ke? I'm not a Nigerian.

A: Oh, you're a Jamaican. I've forgotten. Which place are you from in Jamaica?

F: In Jamaica? Oh ... You know Bob Marley?

A: Eh ... I've heard of him.

F: At the back of ... That is Bob Marley village gan, at the back of it.

A: Ehn, ehn. (bemused)

D: (singing) Naira pool, omo gb'ade ro.

A: (to B) S'eyin ni Naira Pool?

B: Rara o...

G: Where is the second $\$ 50$

A: This man, you're not Yoruba (to F)

F: I am not Yoruba.

D: Naira pool, omo gbade ro.

A: You are from Edo?

F: Edo ke? Ah, ah, no. I'm from the only state in Nigeria.

A: What is the name? What is the name?

F: The ' $\mathrm{D}$ ' State, ehn. The ' $\mathrm{D}$ ' State, that is it.

A: O ga o. Uhn, Na you be Warri man.

F: (pause)

A: No be Warri? You be Asaba.

F: You're talking now. When you talk of ... When you talk of Delta ...

A: I want to hear that una sound wey una dey speak so ... that una broken, I want to hear am self.

F: Our broken?

A: Ehn ... ehn.

F: That one we don drop am o. The time wey den kill ... ehm ... Saro Wiwa.

B: O ma bami sise, o $\mathrm{n}$ ba won ro'jo.

A: No. Ejo, mo $n$ bo naa.

A: Saro Wiwa is not from Delta now, Saro Wiwa is not from Delta.

F: Saro Wiwa is from where?

A: He's from Rivers now.

F: You're right. That's a slip of mouth.

A: (smiling) Not a slip of tongue again.

F: Not a slip of tongue.

D: I be omo Yoruba. Na $\$ 5$ we dey ta si here.

F: He suppose know. He is a politician. (to $G$ )

A: Ehn, ehn, they may ask them during a debate.

B: Kini ten so ye o. Won le fi jay an. 
B: Ejo, $\mathrm{n}$ t'o ri Oloun, se 'born to rule' ni won?

$\mathrm{H}$ : Each state ni won ni ko mu ... n ti won wa submit ni yen.

B: $\mathrm{N}$ ti won submit ni yen.

A: Won ni won bere l'owo Edo State n'igba t'oko 'Heartbeat' k'o wa explain l'Abuja.

F: Dem explain am now. Dem explain am.

F: P. H. Na 'tre $\left(\int\right) o^{\prime}$ base .

A: You be Imo? Oga?

D: Eh?

A: You be Imo? You come dey speak Yoruba like ehn ...

G: Eni ti won bi s'aba aponrin. Na dis Aba wey dey here. Im Mama na Yoruba.

F: When dem go create Ibadan State, dem go come give una Foko Local government.

G: Mo tun ti bere ki nma fin ball win fun opponent.

A: K'e ma se kini fun opponent?

[End]

\section{Appendix II}

Context: On the Street

Interlocutor Y: So, ko try lati intensify effots e.

Z: Ma wa wa. Church kanna l'emi ati woman yen jo nlo.... So, n ma ri l'ola.

Y: Then.

Z: Monday ma, ma tun try lati wa so do e. Ma wa s'odo woman yen gang an. Ma lo ba. Ti $\mathrm{n}$ ba $\mathrm{n}$ be.

Y: Ehn, ehn, o se po. Then, the other ile yen na. Bi o tie s'omi, as long as to ba $t^{\prime}$ obi. To de look fine die na.

$\mathrm{Z}$ : Bi o ba tile wo nu.

Y: To ba wo'nu bawo?

Z: To ba jina sinu l'ohun.

Y: To ba wa ni are 'bi titi kuro. O si better.

$\mathrm{Z}$ : O si better. Whatever the case may be, ma wish lati gbo feedback l'ola. 


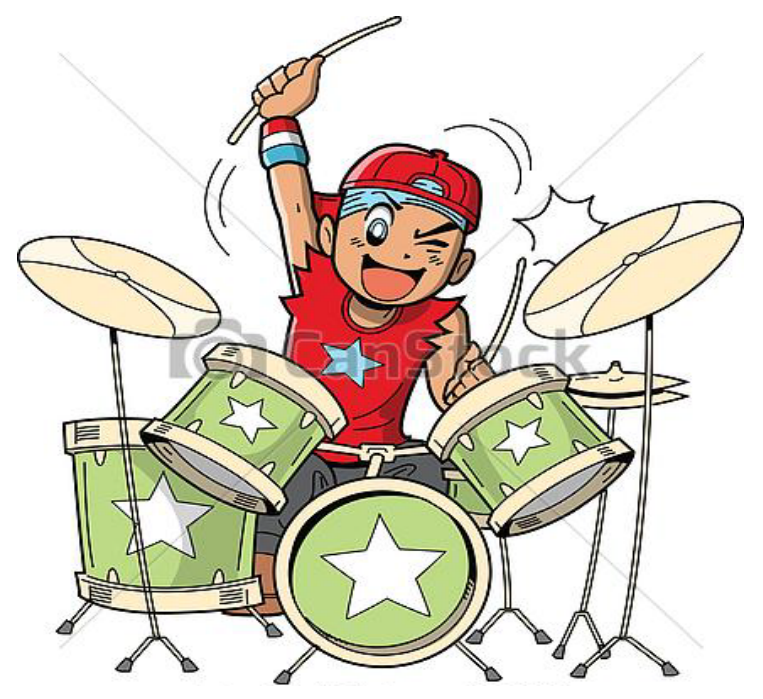

Drummer

A drummer, sick of all the drummer jokes, decides to change his instrument. After some thought, he decides on the accordion. So he goes to the music store and says to the owner, "I'd like to look at the accordions, please." The owner gestures to a shelf in the courner and says, "All our accordions are over there." After browsing, the drummer says, "I think I'd like the big red one in the corner." The store owner looks at him and says, "You're a drummer, aren't you?" The drummer, crestfallen, says, "How did you know?" The store owner says, "That 'big red accordion' is the radiator."

(Source: http://www.study-express.ru/humour/funny-stories.shtml, picture: www.google.co.id) 